\section{Ophir: \\ Bougainville's epic struggle for freedom}

Ophir: Decolonize. Revolutionize, directed by Alexandre Berman and Olivier Pollet. Arsam International/Fourth World Films/Ulster University. 2020. 97 minutes. https://www.ophir-film.com/

N OPHIR (2020), a feature length
documentary film about the Bou-
gainville civil war (1989-1998), French filmmakers Alexandre Berman and Olivier Pollet analyse the devastating conflict and under-reported repercussions which continue to reverberate in the region today.

Ophir in the Old Testament (Genesis 10; 1 Kings 10:22) is a land of great mineral wealth exploited by King Solomon. In eastern Papua New Guinea, the people of Bougainville also claim Ophir to be the original name of their remote islands. Like the fabled land, Bougainville is endowed with treasure, predominantly copper and gold. In the late 20th century, exploitation of these was at the centre of a powerful story of colonialism, inequality, war and redemption.

In the 1960s, when the islands were under Australian administration, the Panguna copper mine was developed

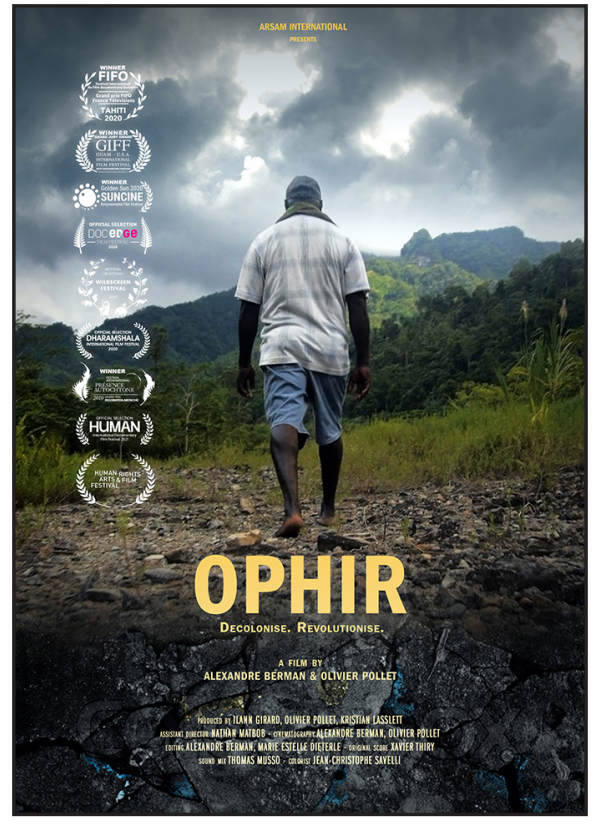

in Central Bougainville in association with Rio Tinto, the mining multinational. Over the years of its operation, rising anger among indigenous communities about environmental devastation, negative social effects and inequitable profits distribution triggered an armed local uprising in 1989.

The brutal civil war which ensued hit the world headlines and became renowned as a David and Goliath struggle of our times.

Bougainville's affairs have been covered over the years by a small coterie of dedicated journalists in the region. But an important eyewitness account of the conflict was the 1988 documentary film Bougainville: Our Island, Our Fight by Australian filmmaker, Wayne Coles-Janess, featuring footage of the jungle war and interviews with the revolutionaries. This 
was followed by a focus on the conflict as an eco-uprising in Dom Rotheroe's 2001 film The Coconut Revolution.

Ophir was made by French filmmaker Alexandre Berman and French investigative journalist, director and producer, Olivier Pollet, who worked with a local team, including assistant director, Nathan Matbob and filmmaker, Clive Porabou, to create an evocative re-telling of the conflict and its legacy over the past two decades.

In an $A B C$ radio interview last year, Pollet claimed the people of Bougainville were allowed to freely express themselves in the film. For filmmaking, he continued, is about 'listening' (Ophir, 2020). The story, without a narrator, is told through a sequence of local voices recounting events from the 1960s, when mining exploration began, through soliloquy, poetry and storytelling.

The film opens with the sound of the sea lapping on Bougainville's shore and islanders speaking of their roles as traditional custodians of the land. Indigenous accounts are interspersed with archival news footage of the time, excerpts from corporate videos and consultants' reports, which unpick the colonial mindset of the era.

Especially revealing are the views of American anthropologist Douglas Oliver. He eerily prophesied resistance to the mine, but recommended some baffling prevention strategies, such as encouraging a passion for consumerism among villagers.

Ophir successfully captures the core of the conflict; the opposing indigenous and Western worldviews about the purpose and rights of land ownership. The Melanesian concept of it as the source of sustenance, social cohesion and wellbeing for this and future generations was opposed to the corporate view of the land's wealth as a commodity to be extracted for immediate profit.

The film's framing of the conflict as one of two opposing parties, of Bougainville freedom fighters against political and economic interference by external state and corporate actors, is true. But the prolonged severity of the war was also due to its fragmentation.

Multiple fronts developed as factions formed, new armed groups broke away from the main BRA (Bougainville Revolutionary Army) and local vendettas complicated hostilities (Regan, 2014).

Significantly, Ophir covers what has happened in the war's aftermath, local expectations of the referendum on Independence held in 2019 and how the Panguna mine has, once again, become controversial. Political leaders call for its reopening in order to bankroll Bougainville's ambition to become a nation state. However, responses are divided in mine-affected communities, where past demands for reparations remain unmet and suspicion of power grabbing by outsiders has not dissipated.

The power of Bougainville's story is that it's a struggle with universal resonance, of the oppressed against the powerful, of right against might. Ophir's directors also see the conflict through a lens of contemporary issues, 
including of global warming and the race for natural resources.

Ophir exposes an important truth: The fight for freedom isn't over. The rebels won the war and secured, with the peace agreement, a degree of autonomy from PNG. However, Bougainville remains financially shackled to the national government and international aid donors for its administrative functioning and post-conflict reconstruction.

As a Bougainville participant in the film says: 'We are still in the colonial era. The design of the system is the application of the seed of dependency planted in the time of colonialism. Borrow for money, borrow for services, become a slave to the master.'

The filmmakers successfully employ the power of journalistic truthtelling through investigative and self-reflexive methods, through local testimonies and exposing influential modes of power and decision-making. Yet they don't shy away from the highly emotive nature of the story.

They are part of a discernible trend of journalists reporting major stories through documentary film. Better production qualities and compelling storytelling of current affairs are contributing to the genre's rising popularity (Del Barco, 2019).

When public trust in the 'truth' is being undermined by 'fake news' and the pitfalls of social media, they are arguably responding to a greater public hunger for more rigorous in-depth reportage and eyewitness experience (Pierce, 2017).

Ophir has been applauded by
Pacific Islanders. It premiered at the FIFO International Documentary Film Festival in Tahiti in February, 2020, and was awarded the Grand Jury Prize, one of several international honours.

\section{References}

Del Barco, M. (2019, February 19). The documentary is in-and enjoying-an 'Undeniable golden age,', NPR. Retrieved from https://www. npr.org/2019/02/19/696036323/thedocumentary-is-in-and-enjoying-anundeniable-golden-age

Ophir: The story of Bougainville (2020, February 27). ABC $P a-$ cific Mornings. Retrieved from https://www.abc.net.au/radio-australia/ programs/pacificmornings/ophir-thestory-of-bougainville/11970862

Pierce, E. (2017, February 3). The rise and rise of the documentary. Retrieved from https://raindance.org/rise-risedocumentary/

Regan, A. (2014). Bougainville: Largescale mining and risks of conflict recurrence. Security Challenges, 10(2) 74-75. Retrieved from https://www.jstor.org/ stable/26467882 